\title{
The Estimation of Generalized Method Moment Poisson Regression Model on The Prevalence of Acute Respiratory Tract Infection (RTI) in South Kalimantan
}

\author{
Mahpolah1, Suharto² $^{2}$ Arief Wibowo ${ }^{2}$, Bambang Widjanarko Otok ${ }^{3}$ \\ ${ }^{1}$ Health Polytechnic Banjarmasin, Ministry of Health \& Ph.D Student Faculty of Public \\ Health, Airlanga University, Surabaya \\ ${ }^{2}$ Department of Biostatistics and Demography, Faculty of Public Health, Airlanga \\ University, Surabaya, \\ ${ }^{3}$ Laboratory of Environmental and Health Statistic, Institut Teknologi Sepuluh \\ Nopember, Surabaya, INDONESIA
}

Email: ${ }^{1}$ mahpolah@gmail.com, ${ }^{3}$ dr.otok.bw@gmail.com

\begin{abstract}
Acute (RTI) is still an important health problem because the cause of the death of infants and children under five high enough, 1 from 4 death that happens. The purpose of this research examines the factors that affect the genesis Acute (RTI) using poisson regression approach with estimates of the maximum likelihood estimator (MLE) and generalized method moment (GMM). This research done in the area of Health Clinic in South Kalimantan. The results of the study showed that the estimates of the GMM method on Poisson regression model gives better performance in terms of the significance of the parameters than the MLE method. The factors that affect an increasing number of the prevalence of Acute (RTI) a region namely persentase Breast Feeding non-exclusive (0.0279), the percentage of low birth weight $(0.0569)$, the percentage of shelter density (0.028), the percentage of the existence of smoker family members in the house (0.0308), the percentage of immunization is not complete (0.0193). While the factors that affect a downturn in the number of the prevalence of Acute (RTI) in a region which is the percentage of the number of infants less than 2 (0.0364), the percentage of normal nutrition status (0.0224), the percentage of Mothers Education on high school (0.0339), and the percentage of social economy (UMP enough to top) (0.0194).
\end{abstract}

Keywords: Poisson Regression, MLE, GMM, Acute (RTI)

\section{INTRODUCTION}

Acute Respiratory Tract Infection (Acute (RTI)) is a disease of the respiratory tract with special attention on the lung inflammation (Phenomonia), and not the disease ear and throat. Acute (RTI) is acute respiratory tract, this term covers three basic namely, respiratory tract infections and acute. The infection is the entry of germs or microorganisms into the human body and multiply so that cause symptoms of disease. The respiratory tract is an organ of such as the nose until the alveoli and adneksnya organs such as the sinus sinus middle ear cavity and pleora. Acute (RTI) are anatomically include infection of the respiratory tract infection [1]. Each child is expected to experience 3-6 episodes Acute (RTI) every year, $40 \%-60 \%$ from the visit in the clinic is by disease Acute (RTI) [2]. 
Acute (RTI) more occurs in developing countries compared to developed countries with the percentage of each by $25 \%-30 \%$ and $10 \%-15 \%$. The death of infants due to Acute (RTI) in Southeast Asia as much as 2.1 million infants in 2004. India, Bangladesh, Indonesia and Myanmar are a country with the case of the death of infants due to Acute (RTI) majority votes [3]. Each year the number of patients with Acute (RTI) in Kalsel shows a significant increase, 2010 is no more than 100 thousand cases occurred in South Kalimantan. The case of Acute (RTI) dyspnea, data Public Health Service South Kalimantan until October 2010 find as much as 963 cases spread in 13 districts. Then to Acute (RTI) not breathing difficulty there are 119.350 cases, also spread in 13 regencies/cities [4]. According to the data from the District health office Tanah Bumbu years 2014 on the moon January-december acquired infants who could anticipate Acute (RTI) as much as 27.457 [5].

The research that related with Acute (RTI), [6] and [7], GMM estimation method on logistic regression model gives better performance in terms of the significance and interpretation than MLE method. The prevalence of Acute (RTI) on children 6-12 months more often occurs in children who are not given breast milk, on children with low birth weight (BBLR) $(<2500$ grams). According [8], which means there is a correlation between the level of zinc hair with genesis Acute (RTI), and there is a correlation that means between the level of zinc with genesis diarrhea in infants stunting of entities exist and infants under normal. On the condition of the zinc that low in the body more vulnerable to the bacteria that produce the toxin.

Bad Breast feeding in Indonesia, limited food supplies in the household levels and limited access infants sick toward quality health services cause 5 million children suffered malnourished [9]. Risk factors that can cause the genesis Acute (RTI) is the internal factors consist of the age of approximately 2 months, BBLR, male, setatus nutrient deficiency of vitamin A, membendong children, (blanketed excessive force), providing additional food too early while factor outward signs are exclusive breastfeeding, immunization, air pollution (smoking habit family members normally housed infants live ), density shelter, fentilasi less sufficient and social economy [10]. Based on that, this research examines the factors that affect the genesis Acute (RTI) based on risk factor in the Clinic in South Kalimantan mnggunakan poisson regression with GMM approach.

\section{METHODS}

Research data is secondary data, namely the number of the prevalence of Acute (RTI) [11] and risk factors in the region of South Kalimantan Clinic. The framework of the concept of the Genesis Acute (RTI) as follows. 


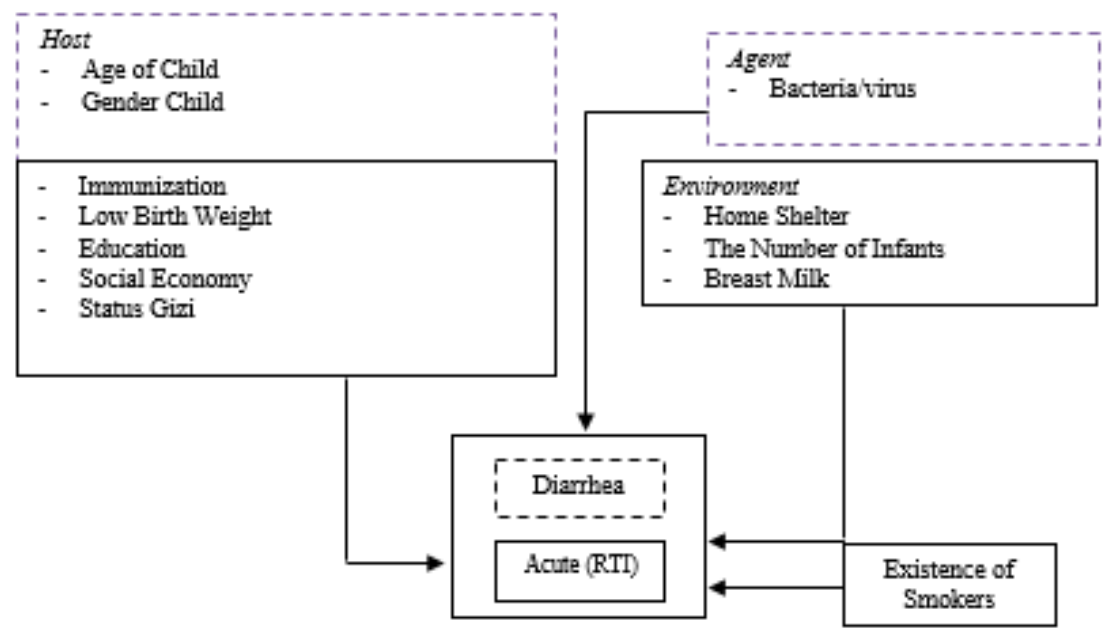

Figure 1. Conceptual Framework Application research [12][7]

Based on the figure 1, then the method used is poisson regression with GMM approach [13][14]. Poisson regression used to analyze verified response variable discrete graphics, where observabel response $(\mathrm{Y})$ be cacahan object that is a function of a number of specific characteristics (x). Probability of $\mathrm{Y}$ "many a genesis" Poisson distribution namely [15].

$$
P(Y=y ; \mu)=\frac{e^{-\mu} \mu^{y}}{y !}, y=0,1,2, \ldots \quad(\mathrm{y}=0,1,2, \ldots)
$$

With $\mu$ is the average number of Genesis that berdistribusi Poisson. Parameters $\mu$ are very dependent on the specific unit or a specific period of time, the distance, wide, volume and etc. Poisson distribution is used for are modeling genesis which is relatively rare during a specific time interval.

The Poisson regression model used the $\log$ function is $\ln (\mu \mathrm{i})=\eta \mathrm{i}$, so that the function of the relationship is served on the common (2) and similarities (3) [13]

$$
\begin{aligned}
& \ln \mu_{i}=\beta_{0}+\beta_{1} x_{1 i}+\beta_{2} x_{2 i}+\ldots+\beta_{k} x_{k i} \\
& \mu_{i}=\exp \left(\mathbf{x}_{\mathbf{i}}^{\mathrm{T}} \boldsymbol{\beta}\right)=\exp \left(\beta_{0}+\beta_{1} x_{1 i}+\beta_{2} x_{2 i}+\ldots+\beta_{k} x_{k i}\right)
\end{aligned}
$$

GMM method is an extension of the estimation of the moment method [16]. The moment the condition of the population to represent the information that will be used. GMM method takes the concept of the estimation of the moment method, where if at the moment method the number of moment conditions with the number of parameters that are being estimated, while for GMM method the number of moment conditions is greater or equal to the number of parameters that are being estimated. The moment the condition is a function of the model parameters and data that has been determined so that the value of the hope of the function is zero on the real value of the parameter. The steps the implementation of poisson regression analysis with estimates of the GMM as follows [17]:

a. The identification of the data research

b. Perform a descriptive analysis of the response variable and variables predictors of research data

c. Use and modify the algorithm GMM on software $\mathrm{R}$ based on the package 
d. The interpretation of the parameter coefficient through the value $\mu_{i}=\exp \left(\mathbf{x}_{\mathbf{i}}^{\mathrm{T}} \boldsymbol{\beta}\right)$

\section{RESULTS AND DISCUSSION}

The response variables used in this research is the number of the prevalence of Acute (RTI) in South Kalimantan Province 2016. The number of cases of Acute (RTI) follow poisson distribution, this is demonstrated through the Kolmogorov Smirnov test with the value Asymp. Sig. ( 2 tailed $)=0.329$ greater than $\alpha=5$ percent then failed to reject Ho, which means that the data follow Poisson distribution.

Descriptive statistics variables predictors that affect the amount of the prevalence of Acute (RTI) in South Kalimantan are presented in the following table.

Table 1. Research Variable descriptive statistics

\begin{tabular}{lrrrr}
\hline Variable & Min & Max & Mean & $\begin{array}{c}\text { Std. } \\
\text { Deviation }\end{array}$ \\
\hline The percentage of non-exclusive breastfeeding (X1) & 0.00 & 7.00 & 4.03 & 2.34 \\
The percentage of low birth weight (X2) & 0.00 & 51.61 & 14.57 & 11.46 \\
The percentage of the number of infants less than 2 (X3) & 2.89 & 28.26 & 14.58 & 5.35 \\
The percentage of normal nutrition status (X4) & 54.35 & 100.00 & 85.27 & 10.53 \\
The percentage of Mothers Education on high school (X5) & 56.31 & 99.27 & 87.49 & 9.55 \\
The percentage of social economy (UMP enough to top) (X6) & 0.00 & 37.09 & 21.05 & 6.77 \\
The percentage of shelter density (X7) & 22.22 & 86.36 & 46.15 & 14.09 \\
The percentage of the existence of smokers family members in the house (X8) & 0.00 & 33.96 & 20.47 & 6.43 \\
The percentage of immunization is not complete (X9) & 0.00 & 79.54 & 30.63 & 15.77 \\
\hline
\end{tabular}

Table 1 shows that the average percentage of non-exclusive breastfeeding (X1) of $4.03 \%$ with standard deviation $2.34 \%$, the average percentage of low birth weight (X2) of $14.57 \%$ and standard deviation $11.46 \%$, the average percentage of the number of infants less than 2 (X3) of $14.58 \%$ and standard deviation $5.35 \%$, the average percentage of normal nutrition status (X4) of $85.27 \%$ with standard deviation $10.53 \%$, the average percentage of Mothers Education on high school (X5) of $87.49 \%$ with standard deviation $9.55 \%$, the average percentage of economic social (UMP enough to top) (X6) of $21.05 \%$ and standard deviation $6.77 \%$, the average percentage of shelter density (X7) of $46.15 \%$ with standard deviation $14.09 \%$, the average percentage of the existence of smokers family members in the house (X8) of $20.47 \%$ with standard deviation $6.43 \%$, and the average percentage of immunization is not complete (X9) of $30.63 \%$ and standard deviation $15.77 \%$.

The results of GMM estimation in the regression model poisson processed through package $\mathrm{R}$, as follows:

Table 2. The estimation of Poisson Regression Model Parameters on Genesis Acute (RTI)

\begin{tabular}{|c|c|c|c|c|c|c|c|c|}
\hline \multirow{3}{*}{ Variables } & \multicolumn{8}{|c|}{ Poisson Regression } \\
\hline & \multicolumn{4}{|c|}{ MLE } & \multicolumn{4}{|c|}{ GMM } \\
\hline & Estimate & $\begin{aligned} \text { Std. } \\
\text { Error }\end{aligned}$ & Sig. & $\mu_{i}$ & Estimate & $\begin{aligned} \text { Std. } \\
\text { Error }\end{aligned}$ & Sig. & $\mu_{i}$ \\
\hline Intercept & 1.3078 & 0.478 & 0.006 & 3.6980 & 3.9395 & 0.937 & 0.000 & 51.395 \\
\hline $\begin{array}{l}\text { The percentage of non-exclusive } \\
\text { breastfeeding (X1) }\end{array}$ & -0.0003 & 0.004 & 0.922 & 0.9997 & 0.0279 & 0.008 & 0.000 & 1.0283 \\
\hline $\begin{array}{l}\text { The percentage of low birth weight } \\
\text { (X2) }\end{array}$ & 0.0200 & 0.006 & 0.002 & 1.0202 & 0.0569 & 0.014 & 0.000 & 1.0585 \\
\hline $\begin{array}{l}\text { The percentage of the number of } \\
\text { infants less than } 2 \text { (X3) }\end{array}$ & -0.0061 & 0.003 & 0.051 & 0.9939 & -0.0364 & 0.006 & 0.000 & 0.9642 \\
\hline The percentage of normal nutrition & 0.0033 & 0.004 & 0.349 & 1.0033 & -0.0224 & 0.009 & 0.009 & 0.9778 \\
\hline
\end{tabular}


status (X4)

The percentage of Mothers

Education on high school (X5)

The percentage of social economy

(UMP enough to top) (X6)

The percentage of shelter

density (X7)

The percentage of the existence of smokers family members in the

house (X8)

The percentage of immunization is not complete (X9)

$\begin{array}{lccccccc}-0.0030 & 0.005 & 0.567 & 0.9970 & -0.0339 & 0.010 & 0.000 & 0.9666 \\ 0.0023 & 0.002 & 0.346 & 1.0023 & -0.0194 & 0.009 & 0.027 & 0.9808 \\ 0.0031 & 0.005 & 0.574 & 1.0031 & 0.0280 & 0.010 & 0.003 & 1.0284 \\ & & & & & & & \\ -0.0029 & 0.002 & 0.203 & 0.9971 & 0.0308 & 0.008 & 0.000 & 1.0313 \\ & & & & & & & \\ 0.0001 & 0.003 & 0.967 & 1.0001 & 0.0193 & 0.007 & 0.005 & 1.0194\end{array}$

Table 2 shows with MLE method that the variables X3, X5, X6 significant because the value of Sig smaller than $\alpha=5 \%$, while with GMM method, all variables are statistically significant. The Model with the value of Goodness of Fit a small said a good model, GMM method is better than the MLE method. The Model is obtained from the results of the GMM estimation is as follows:

$\log \left(\hat{\mu}_{i}\right)=3.940+0.028 X_{1}+0.057 X_{2}-0.036 X_{3}-0.022 X_{4}-0.034 X_{5}-0.019 X_{6}+0.028 X_{7}+0.031 X_{8}+0.019 X_{9}$ Then,

$\hat{\mu}_{i}=\exp \left(3.940+0.028 X_{1}+0.057 X_{2}-0.036 X_{3}-0.022 X_{4}-0.034 X_{5}-0.019 X_{6}+0.028 X_{7}+0.031 X_{8}+0.019 X_{9}\right)$

So that the interpretation of each variable to Genesis Acute (RTI) as follows:

- The percentage of non-exclusive breastfeeding (X1)

Each there is increasing the percentage of non-exclusive breastfeeding (X1) then the average number of the prevalence of Acute (RTI) will increase by 1.0283 times from an average of arata prevalence number of Acute (RTI) conditions with all other variables constant. This is in line with the research of [18] stating that the things that can affect the genesis pneumonia in children is the lack of breast milk as the food naturally can optimize the immune system in the body of the son.

- $\quad$ The percentage of low birth weight (X2)

Each there is increasing the percentage of low birth weight (X2) then the average number of the prevalence of Acute (RTI) will increase by 1.0585 times from an average of arata prevalence number of Acute (RTI) conditions with all other variables constant. This is also in line with the research of [18] stating that the things that can affect the genesis pneumonia in children is BBLR. Infants with low birth weight (BBLR) shows a tendency to more susceptible to infection than infants with birth weight normal (BBLN) and it is the cause of the high level of the death of the baby.

- The percentage of the number of infants less than 2 (X3)

Each there is increasing the percentage of the number of infants less than 2 (X3) then the average number of the prevalence of Acute (RTI) will fell 0.9642 times from an average of arata prevalence number of Acute (RTI) conditions with all other variables constant. This is in line with the research of [19], which states that the number of infants who live together and genesis Acute (RTI) depends on the origin of the disease, namely tetular or not

- The percentage of normal nutrition status (X4)

Each there is increasing the percentage of normal nutrition status (X4) then the average number of the prevalence of Acute (RTI) will fell 0.9778 times from an average of arata prevalence number of Acute (RTI) conditions with all other variables constant. 
- The percentage of Mothers Education on high school (X5)

Each there is increasing the percentage of maternal education on high school (X5) then the average number of the prevalence of Acute (RTI) will fell 0.9666 times from an average of arata prevalence number of Acute (RTI) conditions with all other variables constant.

- The percentage of social economy (UMP enough to top) (X6)

Each there is increasing the percentage of social economy (UMP enough to top) (X6) then the average number of the prevalence of Acute (RTI) will fell 0.9808 times from an average of arata prevalence number of Acute (RTI) conditions with all other variables constant. Children with socio-economic status less has the possibility of experiencing Acute (RTI) higher compared with children with high economic social status. This can be explained that the socioeconomic status influence on education and other factors such as nutrition, lingkuingan and acceptance of health services. Parents who come from high economic social level better able to provide a healthy food vitamins and supplements that can help improve the health status of the family. Children who come from families with low socio-economic status have a greater risk of experiencing Acute (RTI).

- The percentage of shelter density (X7)

Each there is increasing the percentage of shelter density (X7) then the average number of the prevalence of Acute (RTI) will increase by 1.0284 times from an average of arata prevalence number of Acute (RTI) conditions with all other variables constant.

- The percentage of the existence of smoker family members in the house (X8)

Each there is increasing the percentage of the existence of smoker family members in the house (X8) then the average number of the prevalence of Acute (RTI) will increase by 1.0313 times from an average of arata prevalence number of Acute (RTI) conditions with all other variables constant. This shows that one of the causes of children experiencing the attack Acute (RTI) because the family members are smoking so that children were exposed to smoke that cause an attack Acute (RTI)

- The percentage of immunization is not complete (X9)

Each there is increasing the percentage of immunization is not complete (X9) then the average number of the prevalence of Acute (RTI) will increase by 1.0194 times from an average of arata prevalence number of Acute (RTI) conditions with all other variables constant. Children with incomplete immunization status has the possibility of experiencing higher compared with children with complete immunization status. It is related with measles, pertussis and some other disease can increase the risk Acute (RTI) and weighed Acute (RTI) itself, but actually it can be prevented. Measles, Pertussis and Difteri together can cause 15-25 percent of all deaths related to Acute (RTI).

\section{CONCLUSIONS}

Based on the analysis of the data and the discussion it can be concluded that the number of the prevalence of Acute (RTI) in South Kalimantan Province follow poisson distribution, so used Poisson regression modeling. The results of the study showed that the estimates of the GMM method on Poisson regression model gives better 
performance in terms of the significance than MLE estimation method. The factors that affect an increasing number of the prevalence of Acute (RTI) a region caused namely persentase Breast Feeding non-exclusive (X1), the percentage of low birth weight (X2), the percentage of shelter density (X7), the percentage of the existence of smoker family members in the house (X8), the percentage of immunization is not complete (X9). While the factors that affect a downturn in the number of the prevalence of Acute (RTI) in a region because of the variables the percentage of the number of infants less than 2 (X3), the percentage of normal nutrition status (X4), the percentage of Mothers Education on high school (X5), and the percentage of social economy (UMP enough to top) (X6).

\section{REFERENCES}

[1] J. M. Wantania, R. Naning, A. Wahani, Infeksi Respiratori Akut. Buku Ajar Respirologi Anak Edisi Pertama, Ikatan Dokter Anak Indonesia, Jakarta, 2008.

[2] W. Purnomo, Hubungan Antara Pengetahuan dan Sikap Ibu Dengan Upaya Pencegahan ISPA Pada Balita di Puskesmas Ngoresan Surakarta, Fakultas Ilmu Kesehatan Universitas Muhammadiyah Surakarta, Surakarta, 2008.

[3] WHO, Penanganan ISPA Pada Anak di Rumah Sakit Kecil Negara Berkembang, Penerbit Buku Kedokteran EGC, Jakarta, 2012.

[4] Dinas Kesehatan Propinsi Kalimantan Selatan, Profil Kesehatan Propinsi Kalimantan Selatan, Dinkes Prop. Kalsel, Banjarmasin, 2014.

[5] Dinas Kesehatan Kabupaten Tanah Bumbu, Profil Kesehatan Kabupaten Tanah Bumbu, Dinkes Prop. Kalsel, Banjarmasin, 2014.

[6] Mahpolah, Suharto, W. Arief, B. W. Otok, "Generalized Method Moment Logistic Regression Model on the Prevalence of Acute Respiratory Tract Infections," J. Appl. Environ. Biol. Sci., 7(10)92-96, 2017.

[7] S. E. Purwanengsi, Kuntoro, P. Windu, B. W. Otok, "The Modeling Level of Birth Weight Using a Maximum Likelihood Estimation and Generalized Method of Moment," J. Appl. Environ. Biol. Sci., 6(7)125-128, TextRoad Publication, 2016.

[8] D. Arini, B. W. Otok, E. Dwi, "The Modeling of Acute Respiratory Tract Infections (RTI) On Children 6-12 Months with Multinomial Logit Approach," J. Basic. Appl. Sci. Res., 6(9) 1-6, 2016.

[9] A. Arwin dan N. Zakiudin, Alergi-Imunologi Anak, Edisi 2, Jakarta, Badan Penerbit IDAI, 2010.

[10] DepKes RI, Rencana pembangunan jangka panjang bidang kesehatan 2005-2025, Direktorat Jendral Bina Kesehatan Masyarakat, Jakarta, 2009.

[11] D. Pramono, Besar sampel dalam penelitian kesehatan Yogyakarta: Gadjah Mada University Press. Edisi terjemahaan dari: Lemeshow, S., Hosmer, D.W., Klar, J., Lwanga. (1990) Adequacy of sample size in health studies. WHO: John Willey \& Sons, 1997.

[12] G. Lawrence and A. Ruth, Breastfeeding: A guide for the medical profession, Fourth Edition, St. Louis: Masby: 9-40, 1994.

[13] A.C. Cameron and P.K. Trivedi, Regression Analysis of Count Data, Cambridge: Cambridge University Press, 1998.

[14] P. Chausse, "Computing Generalized Method Of Moments With R," Journal Of Statistica, vol.34, 2010.

[15] F. Famoye, S. Bae, J.T. Wulu, A.A. Bartolucci, K.P. Singh, "On the Generalized Poisson Regression Model with an Application to Accident Data," Central 
Michigan University, Bureau of Primary Health Care UNT Health Science Center, Journal of Data Science, 2(2004), 287-295, 2004.

[16] A. R. Hall, "Generalized Method Of Moments: Advanced Text In Econometrics," Oxford University Press Inc: New York, 2005.

[17] T. R. Muhammad, B. W. Otok, I. N. Latra, "Estimation of Generalized Method of Moment in Logistic Regression Model," Prosiding Seminar Nasional Matematika, Universitas Jember, 167-174, 2014.

[18] C.G. Voctora, B. R. Kirkwood, B.R. Ashworth, R. E. Black, S. Rogers. "Potential Interventions for the Prevention of the Childhood Pneumonia in Developing Coutries: Improving Nutrition," Am J ClinNutr, vol.70, pp. 309 - 320, 1999.

[19] R. B. Darmawan, Buku Ajar Respirologi Anak. Edisi I. Badan Penerbit IDAI, Jakarta, 2010. 